177 Double triggered HASTEを用いたwhole body non enhanced MRAの試み

東京慈恵会医科大学附属病院・放射線部 松田直子，北川 久

斎藤 亮, 庄司友和, 石崎雅俊，岸 孝幸，矢本俊一

【目的】今回，横隔膜同期法であるPACE (Prospective Acquisition and CorrEction)ならびに心電図同期併用可能なDouble triggered HASTE (Half fourier acquisition single shot turbo spin echo) が開発された。さ らに動静脈分離を可能にすべく Read-Out-flow-spoilが印加されたシー ケンスを用いて，Tim(Total imaging matrix) システムを用いたWhole Body non enhanced MRAを試みたので報告する。

【使用装置】SIEMENS社製 MAGNETOM Avanto1.5T

【方法】健常ボランティア(施設承認済み)を対象に胸部領域，腹部領 域，骨盤領域，下肢領域に扔ける撮像を行う。各検討項目は 1 ,

Read-out-flow-Spoil強度の最適化 2, Echo-Spacingの最適化 3, 脂 肪抑制有無の最適化 4, Trigger delay incrementによるTrigger delay timeの最適化 5, PACE使用に㧍ける吸気呼気時の血流信号変化

6, 最適化されたECG-triggered HASTEを用いて臨床報告.

【結果, 考察】今回最適化されたDouble triggered HASTEを用いて Whole body non enhanced MRAが可能になった。しかし撮像時間延 長による体動のアーチファクトによってSubtraction不良が起きるこ とがある.また各部位におけるRead-out-flow-spoil強度の設定, 貯留 水の有無による画像描出の变化があり今後検討していきたいと考え る.

178 FBIを用いた鎖骨下動脈における至適撮像条件の検討 第 2 報

埼玉県済生会栗橋病院・放射線科 渡邊城大

さいたま市立病院・中央放射線科 藤田 功, 打田隆夫

日本医科大学付属病院・放射線科 土橋俊男

東芝メディカルシステムズ 宮田知子，喜種慎一，宮崎美津恵

【目的】第61回総会にて，FBIで鎖骨下動脈を描出するためには，k-空 間中心までのdelay timeを100ms（TE30msにて設定70ms）および500ms (設定 $470 \mathrm{~ms}$ ) 付近で撮像しサブトラクション処理することが必要で ある旨を発表したが，脂肪抑制のためIR $\left(180^{\circ}\right)$ パルスを用い，100ms 前後で撮像しても，背景信号を抑制することはできなかった，今回 我々は，原画での背景信号の抑制を目的に検討を行ったので報告す る.

【使用機器】ExcelArt XG 1.5T(東芝メディカルシステムズ社製)，QDTorso Speederコイル

【方法】ボランティアにて (1)IRパルスの強度を変化させ (通常より浅 く)背景信号の抑制効果と血管の描出能について検討した。（2）Fat satパルスの有無について (1) と同様に検討した。（3)臨床応用。な お，ボランテイアには本研究の目的㧍よび臨床的な意義を十分説明 し，同意を得たうえで撮像を行った。

【結果・考察】IRパルスを浅くすることにより delay timeを延長するこ となく背景信号を抑制することができ，原面での血管の描出能が向 上した. Fat satについては, 不均一になりやすく, 広範囲の撮像に は注意が必要である。

【結語】非造影であるFBIは流速の早い鎖骨下動脈において 2 shot, SF1.5を使用し，浅いIRパルスにすることにより背景信号も抑制し， ついては良好な画像が得られ有用と考えられる。

\section{9 䅡部MRAの描出能改善の試み}

奈良県立医科大学附属病院・中央放射線部 野儀明宏, 樋垣 誠 山谷裕哉。进 司

【目的】大動脈弓部から䅡部のMRAを撮像する際，当施設ではcoronal あるいはcoronal obliqueによる造影MRAまたは，3d TOF法を用いた 横断像をMIP処理にて行っていた。しかし，3d TOF法では大動脈か
らの頭部血管の三本分岐が十分描出できないこともある。また，造 影MRAは造影剤を使用するという浸襲性があり, 多数回の検査を容 易に行うことは困難である，そこで今回， $2 \mathrm{dTOF}$ T法に脈派同期を併 用することにより画質の改善を試みた。

【使用装置】シーメンス社製 MR Impact Expert Turbo 1.0T

【方法】2d TOF法においてスライス厚を最小の $3 \mathrm{~mm} に$ 固定し，スラ イスオーバーラップの值を変化させ, 多方向からのMIP画像による 検討を行った。 また, 脈派同期のdelay timeを変化させた時の描出能 の検討を行ったささらに $2 \mathrm{~d}$ TOF法と従来の $3 \mathrm{~d}$ TOF法による画像の 比較検討を行った。

【結果】 $2 \mathrm{~d}$ TOF法に脈派同期を併用することにより大動脈弓部の三本 分岐の描出能が改善した。 また，スライスオーバーラップすること により, MIP画像での多方向からの観察が可能であった。

180 マンモグラフィ追加撮影時におけるフローチャート作成と有用 性の検討 (第 2 報)

聖マリアンナ医科大学横浜市西部病院・画像診断部 西山健一 池田裕三, 武末雅史, 鈴木清文, 宮崎寿哉, 久米由香, 岩瀬雅則 【目的】第61回総会学術大会にて, マンモグラフィー追加撮影時にお けるフローチャート作成とその有用性について報告した。前回で は, 主に主要所見別(腫瘤, 石灰化, その他の所見)に追加撮影方法 を分類したが, 今回はさらに，接線撮影やロール撮影などを含め， 病変が位置する領域とスポット撮影の方向, 撮影枚数について, 被 ばくも考慮し，検討を加えた。また通常，追加撮影を行わない，明 らかなカテゴリー5の病変でも, 手術に有用な情報を提供できれ ば，追加撮影の対象としてフローチャートに反映できないか検討し た。

【方法・結果】1. 前回同様, 装置的な追加撮影と, 手技的な追加撮影 に加え, 病変の位置する領域に対し, 最も有意であると思われる撮 影方法及び撮影方向そして撮影枚数について, 検討を行いフロー チャートに反映させた．2. 明らかなカテゴリー5の症例について， 追加撮影が必要か，また必要とした場合，どのような追加撮影が， 有用な情報であるかを外科医と検討しフローチャートに反映させ た. 3.フローチャートに従い撮影した臨床症例で, 特に有意であっ たものについて報告する.

【考察】追加撮影する場合, 標準撮影 (CC, MLO) とは, 異なる方法 で撮影することで, 情報量を多くし, 情報の質を高めることが, 最 も重要である.今回, 接線撮影やロール撮影を含め様々な撮影方法 を, フローチャートに反映させたことで, 撮影者が, その撮影方法 の優位性や目的を理解することができ, 追加撮影の質を高めること ができた．また実際，乳がんの手術を行う外科医の意見を取り入れ ることで，より実用的なフローチャートを作成することができた。

181 乳腺密度の違いによるマンモグラフイ追加撮影の有用性 大阪府立成人病センター・放射線診断科宮崎正義，中島 直 川東憲治

【目的】追加撮影法は, 形状, 辺縁, 性状などをより詳しく見るため に, 標準撮影法 (CC, MLO) で描出が不十分な病変に対して行われ る.それにより, カテゴリー分類が変わり, 診断に有用なことが多 い. しかし, 乳腺密度によっては, 追加撮影を行っても診断に寄与. しないこともある.今回われわれは, 乳腺密度の違いによる追加撮 影の有用性を検討した.

【方法】対象は, 腫瘤性病変が疑われ, 追加撮影を行った患者70症例 と, 石灰化病変 10 症例であった. 乳腺密度別に, 追加撮影を 5 パ ターンに分け，追加撮影が有用であったか検討を行った。

【結果】1, 脂肪性は, 10 症例中 2 症例のみカテゴリー分類がより悪 性になった。他は変わらなかった。 2 , 散在性は, 10 症例中 1 症例 のみカテゴリー分類がより悪性になった。他は変わらなかった３， 